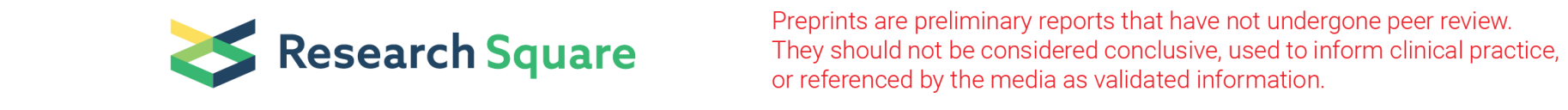

\title{
Bibliometric analysis of Scopus indexed publications on polymyxin resistance (2009-2018)
}

\author{
Alvaro Quincho-Lopez ( $\sim$ alvaro209.ql@gmail.com ) \\ Universidad Nacional Mayor de San Marcos https://orcid.org/0000-0003-3556-0086 \\ Josmel Pacheco-Mendoza \\ Universidad San Ignacio de Loyola
}

\section{Research}

Keywords: polymyxin resistance, bibliometric, Scopus

Posted Date: August 18th, 2020

DOI: https://doi.org/10.21203/rs.3.rs-57951/v1

License: (1) This work is licensed under a Creative Commons Attribution 4.0 International License. Read Full License 


\section{Abstract}

Background: Antimicrobial resistance is a serious public health problem that has become a global threat. Special attention should be given to polymyxins (polymyxin B and colistin) which, since their reintroduction into clinical practice, are considered "last resort" drugs. The objective of this study is to perform a bibliometric analysis of scientific research on polymyxin resistance.

Methods: Scopus database was used to retrieve documents relevant to polymyxin resistance. At the beginning, all kinds of documents without year restrictions were included. Subsequently, the study period (2009-2018) was limited and analyzed using SciVal. Specifically, the 10 institutions and countries with the highest production, authors, journals, and most cited articles were analyzed. The growth of publications and citations was graphed, in addition to an analysis of the keywords using VOSviewer.

Results: A total of 1,306 documents were retrieved (1947-2019). Original articles (76.95\%) and letters to the editor (15.47\%) were the most frequent types of documents. English was the predominant language with 1,270 documents (97.2\%). In the period 20092018 , there was a significant growth in publications ( $p$-value $<0.001)$ retrieving $833(64 \%)$ documents. The received citations were 23,974, with a peak in 2016 (8,033 citations). The United States and China lead the scientific production with 146 (17.5\%) and $137(16.4 \%)$ publications, respectively. University of Fribourg (Switzerland) was the most productive institution on the subject (44 documents), although University of Zhejiang (China) has caused the greatest impact (73.5 citations/article). Antimicrobial Agents and Chemotherapy ranked first with 140 documents. Most of the documents were published in quartile 1 journals (82.7\% and $69.1 \%$, according to Scimago Journal \& Country Rank and CiteScore, respectively).

Conclusions: The number of documents on polymyxin resistance has increased significantly in the recent years. In the last few years alone, $64 \%$ of all documents have been published. The United States and China lead the scientific production. Greater efforts are still needed to tackle this global problem.

\section{Introduction}

Although efforts for the development of new antibiotics are constant, their number is still insufficient, many of these are modifications of existing ones and only ensure temporary control [1]. Meanwhile, antimicrobial resistance (AMR) continues to be one of the main problems in public health, not only because of the high cost at the social level but also because of the high economic cost, therefore urgent actions are necessary to face this global problem [2-4]. The AMR, especially in gram-negative bacteria, has led to the rethinking of drugs that, due to their severe adverse effects, namely nephrotoxicity and neurotoxicity, were neglected more than 30 years ago [5]. Such is the case of polymyxins, a group of polypeptide antibiotics composed of 5 different chemical structures (A-E), of which only polymyxin B and E have clinical relevance, the latter being better known as colistin [6]. Since their reintroduction into clinical practice, they are considered "last resort" drugs because they serve as a final alternative to the ineffectiveness of other drugs [7].

In 2017, the World Health Organization (WHO) in the GLASS (Global Antimicrobial Resistance Surveillance System) report noted that, due to cases of carbapenem resistance, the use of colistin had increased significantly. Although cases of colistin resistance are rare in countries that have the possibility of monitoring it, an emerging resistance to this drug has been noted [8], especially reported in Acinetobacter baumannii [9-11]. Therefore the WHO developed a technical guide for the detection and reporting of colistin resistance [12], in addition to molecular methods to support AMR surveillance [13, 14]. Since then, various efforts have been made by researchers to develop detection mechanisms for polymyxin resistance, mainly in Enterobacteriaceae [15] and gram-negative bacteria [16].

Previously, various drugs have been studied with bibliometric indicators [17, 18], as in the case of some antiparasitics such as antimalarial drugs [19], and antifungals such as triazoles [20]. Antibiotic resistance has also been studied in a general way [21] or individually, either focusing on which organ or system is affected, such as antimicrobial resistance to uropathogens [22], or according to the class of antibiotic, for example those resistant to carbapenem [23]. However, no bibliometric studies on polymyxin resistance have been performed. Although colistin is the best-known example, it is preferred to study the class of antibiotics to which it belongs. In such a way, it is necessary to analyze the information published so far in order to understand the current state of the art in relation to polymyxin resistance, as these will serve as the basis for future plans and actions aimed 
at controlling or reducing the AMR and thereby reduce its impact on health. The objective of this study is to comprehensively analyze research on polymyxin resistance, specifically, bibliometric indicators such as the types of documents, the top ten institutions, countries, authors, journals, and articles in Scopus.

\section{Methods}

The search and data extraction was done in Scopus, due to the fact that it has a greater number of peer-reviewed journals [24]. When performing the search, terms used were extracted from the Medical Subject Headings (MeSH) from Pubmed and Emtree from Embase and from these a complex search strategy was generated:

( ( ( TITLE ( colistin W/1 resist* ) ) OR ( TITLE ( colistimethate W/1 resist* ) ) OR ( TITLE ( colimycin W/1 resist* ) ) OR ( TITLE ( "pol?m?x?n E" W/1 resist*) ) OR ( TITLE ( "pol?m?x?n B" W/1 resist*) ) OR ( TITLE ( pol?m?x?n W/1 resist* ) ) ) OR (KEY ( "colistin resist*" OR "colistimethate resist*" OR "colimycin resist*" OR "polymyxin E resist*" OR "polymyxin B resist*" OR "polymyxin resist*" OR "polymixin resist*" ) ) ) OR ( TITLE-ABS-KEY ( "mobilized colistin resistance" OR "mobile colistin resistance" ) ) AND ( LIMIT-TO ( SRCTYPE, "j" ) ) AND ( EXCLUDE ( PUBSTAGE, "aip" ) ) AND ( EXCLUDE ( DOCTYPE, "er" )) AND ( EXCLUDE (PUBYEAR, $2020))$

The asterisk $\left(^{*}\right)$ was used as a truncator or wildcard to collect all the variants of the word that have a root in common. For example, when you enter resist*, the search engine will show results for both resist-ent and resist-ance. On the other hand, some articles, especially the oldest ones, reported their research with different versions of the same word, such as polymyxin, polymixin, polymyxin, polymyxin, etc. In order to retrieve the largest number of documents, vowels $Y$ and I of "polymyxin" were replaced with the question mark (?), which allows replacing a single character, finally being written as pol?m?x?n. The W/1 was used to search for variants that have a maximum of 1 term or none among the searched words, for example when searching for TITLE (colistin W/1 resist*), titles such as: colistin resistance, resistant to colistin, and resistance to colistin, among others, will be retrieved. The use of acronyms like "mcr" was avoided when formulating the search strategy since they were confused with false positive results such as "Multivariate Curve Resolution (MCR)". The search excluded 2020 results and was performed on 05/18/20. Erratum, articles in press and indefinite articles were also excluded.

Initially, data analysis was performed on 05/19/20 using Scopus. Later, a .csv [Additional file 1: Dataset] file was imported into SciVal for further analysis, limiting the results to a period of 10 years (2009-2018). The data collected included: types of documents, number of publications per year, countries, institutions, journals, and the most productive authors. In addition, the research production of each country was adjusted according to the size of its population (https://www.cia.gov/library/publications/the-world-factbook/geos/ag.html). Pearson's correlation coefficient was obtained through the STATA statistical package (version 15.0, StataCorp, College Station, TX, USA) to check the correlation between some variables (number of documents and number of citations, and the number of documents during the period 2009-2018). The Field-Weighted Citation Impact (FWCl) was used as a bibliometric indicator and is defined as the ratio of the total citations received by a document to the expected number of citations for similar documents [25]. Similar documents include those in the same discipline or area of study, the same type of document, and the same year of publication. It is calculated for the same year of publication and the following three years. Its basal value is 1 , that is, if the $\mathrm{FWCl}$ is greater than 1 , the result is more cited than expected according to the global average [25]. The number of documents per quartile was also counted according to Scimago Journal \& Country Rank (SJR) and CiteScore (CS).

VOSviewer (version 1.6.10) was used to create a visual representation of the co-occurrence of the most relevant keywords [26]. For these frequently encountered terms, a minimum of 100 occurrences was placed as a limit.

\section{Results}

A total of 1,306 results were obtained (1947-2019). Most of the documents (Table 1) were articles (76.95\%), followed by letters to the editor (15.47\%) and then reviews (4.29\%). The 1,306 documents were published in 13 languages. English was the predominant language with 1,270 (97.2\%) documents, followed by Chinese with 12 (0.9\%) documents. Since 1994, there has been at least one publication per year on polymyxin resistance, either colistin or polymyxin B. Before that year, the publications 
were not consecutive and the most frequently cited article discussed the first mechanisms discovered on polymyxin resistance [27].

Table 1

Types of retrieved documents on polymyxin resistance

\begin{tabular}{|c|c|c|}
\hline Type of document & $\begin{array}{l}\text { Frequency } \\
(N=1306)\end{array}$ & $\begin{array}{l}\text { Percentage } \\
(\%)\end{array}$ \\
\hline Article & 1005 & 76.95 \\
\hline Letter & 202 & 15.47 \\
\hline Review & 56 & 4.29 \\
\hline Note & 26 & 1.99 \\
\hline Editorial & 12 & 0.92 \\
\hline Short Survey & 3 & 0.23 \\
\hline Conference Paper & 2 & 0.15 \\
\hline
\end{tabular}

When the analysis was limited from 2009 to 2018, 833 documents were obtained (64\%). With 3,837 authors, there were 23,974 citations, with a peak recorded in 2016 (8,033 citations) and, in addition, 28.8 citations/article were obtained. Figure 1 shows the number of documents and citations on polymyxin resistance. A significant increase in publications was observed during the period 2009-2018 ( $r=0.880, p$-value $<0.001)$, and a moderate correlation between the number of published documents and the number of citations $(r=0.634, p$-value $=0.04)$. The list of the 10 most cited publications on polymyxin resistance is found in Table 2. Of these publications, 2 documents are reviews, the rest are articles, within which is the most cited document on polymyxin resistance. This document was published in The Lancet Infectious Diseases and its number of citations quadruples those received by the second place. 
Table 2

Top ten cited documents on polymyxin resistance (2009-2018)

\begin{tabular}{|c|c|c|c|c|c|c|}
\hline Rank & Author & Title & Year & Source title & $\begin{array}{l}\text { Number } \\
\text { of } \\
\text { citations }\end{array}$ & $\begin{array}{l}\text { Type of } \\
\text { document }\end{array}$ \\
\hline 1 & $\begin{array}{l}\text { Liu Y.-Y. et } \\
\text { al. [29] }\end{array}$ & $\begin{array}{l}\text { Emergence of Plasmid-Mediated Colistin } \\
\text { Resistance Mechanism MCR-1 in Animals and } \\
\text { Human Beings in China: A Microbiological and } \\
\text { Molecular Biological Study }\end{array}$ & 2016 & $\begin{array}{l}\text { The Lancet } \\
\text { Infectious } \\
\text { Diseases }\end{array}$ & 1884 & Article \\
\hline 2 & $\begin{array}{l}\text { Olaitan } \\
\text { A.O. et al. } \\
\text { [45] }\end{array}$ & $\begin{array}{l}\text { Mechanisms of Polymyxin Resistance: Acquired } \\
\text { and Intrinsic Resistance in Bacteria }\end{array}$ & 2014 & $\begin{array}{l}\text { Frontiers in } \\
\text { Microbiology }\end{array}$ & 466 & Review \\
\hline 3 & $\begin{array}{l}\text { Moffatt } \\
\text { J.H. et al. } \\
\text { [11] }\end{array}$ & $\begin{array}{l}\text { Colistin Resistance in Acinetobacter baumannii } \\
\text { Is Mediated by Complete Loss of } \\
\text { Lipopolysaccharide Production }\end{array}$ & 2010 & $\begin{array}{l}\text { Antimicrobial } \\
\text { Agents and } \\
\text { Chemotherapy }\end{array}$ & 363 & Article \\
\hline 4 & $\begin{array}{l}\text { Cai Y. et al. } \\
\text { [10] }\end{array}$ & $\begin{array}{l}\text { Colistin Resistance of Acinetobacter baumannii: } \\
\text { Clinical Reports, Mechanisms and Antimicrobial } \\
\text { Strategies }\end{array}$ & 2012 & $\begin{array}{l}\text { Journal of } \\
\text { Antimicrobial } \\
\text { Chemotherapy }\end{array}$ & 303 & Review \\
\hline 5 & $\begin{array}{l}\text { Tumbarello } \\
\text { M. et al. } \\
\text { [46] }\end{array}$ & $\begin{array}{l}\text { Infections Caused by KPC-producing Klebsiella } \\
\text { pneumoniae: Differences in Therapy and } \\
\text { Mortality in a Multicentre Study }\end{array}$ & 2015 & $\begin{array}{l}\text { Journal of } \\
\text { Antimicrobial } \\
\text { Chemotherapy }\end{array}$ & 262 & Article \\
\hline 6 & $\begin{array}{l}\text { Adams } \\
\text { M.D. et al. } \\
\text { [47] }\end{array}$ & $\begin{array}{l}\text { Resistance to Colistin in Acinetobacter } \\
\text { baumannii Associated with Mutations in the } \\
\text { PmrAB Two-Component System }\end{array}$ & 2009 & $\begin{array}{l}\text { Antimicrobial } \\
\text { Agents and } \\
\text { Chemotherapy }\end{array}$ & 262 & Article \\
\hline 7 & $\begin{array}{l}\text { Yin W. et } \\
\text { al. [31] }\end{array}$ & $\begin{array}{l}\text { Novel Plasmid-Mediated Colistin Resistance } \\
\text { Gene mcr-3 in Escherichia coli }\end{array}$ & 2017 & mBio & 247 & Article \\
\hline 8 & $\begin{array}{l}\text { Hasman } \mathrm{H} \text {. } \\
\text { et al. [44] }\end{array}$ & $\begin{array}{l}\text { Detection of mcr-1 Encoding Plasmid-Mediated } \\
\text { Colistin-Resistant Escherichia coli Isolates from } \\
\text { Human Bloodstream Infection and Imported } \\
\text { Chicken Meat, Denmark } 2015\end{array}$ & 2015 & Eurosurveillance & 225 & Article \\
\hline 9 & $\begin{array}{l}\text { Beceiro A. } \\
\text { et al. [48] }\end{array}$ & $\begin{array}{l}\text { Phosphoethanolamine Modification of Lipid A } \\
\text { in Colistin-Resistant Variants of Acinetobacter } \\
\text { baumannii Mediated by the PmrAB Two- } \\
\text { Component Regulatory System }\end{array}$ & 2011 & $\begin{array}{l}\text { Antimicrobial } \\
\text { Agents and } \\
\text { Chemotherapy }\end{array}$ & 203 & Article \\
\hline 10 & $\begin{array}{l}\text { Carattoli A. } \\
\text { et al. [32] }\end{array}$ & $\begin{array}{l}\text { Novel Plasmid-Mediated Colistin Resistance } \\
\text { mcr-4 Gene in Salmonella and Escherichia coli, } \\
\text { Italy } 2013 \text {, Spain, and Belgium, } 2015 \text { to } 2016\end{array}$ & 2017 & Eurosurveillance & 197 & Article \\
\hline
\end{tabular}

Among the 10 countries with the largest number of documents (Table 3), the United States of America (USA) is in first place with 146 documents and 6,513 citations, followed by China with 137 documents and 5,319 citations. It should be noted that the United Kingdom (UK) despite having fewer articles (44) has a significant number of citations $(3,587)$. 
Table 3

Top ten productive countries on polymyxin resistance (2009-2018)

\begin{tabular}{|c|c|c|c|c|c|c|c|}
\hline Rank & Country & $\begin{array}{l}\text { Documents } \\
\mathrm{N}=833 \text { (\%) }\end{array}$ & $\begin{array}{l}\text { Documents/10 million } \\
\text { inhabitants }\end{array}$ & $\begin{array}{l}\text { Total } \\
\text { citation }\end{array}$ & Citations/document & $\begin{array}{l}\text { International } \\
\text { collaboration; } \\
\text { National } \\
\text { collaboration } \\
(\%)\end{array}$ & $\mathrm{FWCl}$ \\
\hline 1 & $\begin{array}{l}\text { United } \\
\text { States }\end{array}$ & 146 (17.5) & 4.39 & 6513 & 44.6 & $64.4 ; 21.2$ & 4.48 \\
\hline 2 & China & $137(16.4)$ & 0.98 & 5319 & 38.8 & $46.0 ; 38.7$ & 5.13 \\
\hline 3 & France & 99 (11.9) & 14.59 & 3360 & 33.9 & $62.6 ; 33.3$ & 4.31 \\
\hline 4 & Italy & $70(8.4)$ & 11.22 & 2596 & 37.1 & $32.9 ; 45.7$ & 4.39 \\
\hline 5 & Switzerland & $57(6.8)$ & 67.82 & 1715 & 30.1 & $63.2 ; 28.1$ & 5.09 \\
\hline 6 & Spain & $56(6.7)$ & 11.20 & 1594 & 28.5 & $42.9 ; 53.6$ & 3.35 \\
\hline 7 & Brazil & $47(5.6)$ & 2.22 & 722 & 15.4 & $8.5 ; 55.3$ & 1.91 \\
\hline 8 & $\begin{array}{l}\text { United } \\
\text { Kingdom }\end{array}$ & $44(5.3)$ & 6.69 & 3587 & 81.5 & $79.5 ; 6.8$ & 8.80 \\
\hline 9 & Australia & $39(4.7)$ & 15.31 & 1404 & 36.0 & $79.5 ; 15.4$ & 2.92 \\
\hline 10 & $\begin{array}{l}\text { South } \\
\text { Korea }\end{array}$ & $33(4.0)$ & 6.37 & 630 & 19.1 & $9.1 ; 45.5$ & 2.42 \\
\hline
\end{tabular}

Table 4 shows the authors with the highest production on polymyxin resistance. Nordmann P. and Poirel L., both with the same affiliation (University of Fribourg), dominate the list with the largest number of documents (43 each) and a similar number of citations (1,510 and 1,560, respectively). It is important to note that the most influential authors on polymyxin resistance were Doi $Y$. from the USA and Wang $Y$. from China with 2,753 and 2,486 citations, respectively. 
Table 4

Top ten authors publishing on polymyxin resistance (2009-2018)

\begin{tabular}{|c|c|c|c|c|c|c|c|c|}
\hline Rank & Author & Documents & $\begin{array}{l}\text { Total } \\
\text { citation }\end{array}$ & $\begin{array}{l}\text { h- } \\
\text { Index }\end{array}$ & $\mathrm{FWCl}$ & $\begin{array}{l}\text { International } \\
\text { collaboration } \\
(\%)\end{array}$ & Affiliation & Country \\
\hline 1 & $\begin{array}{l}\text { Nordmann, } \\
\text { Patrice L. }\end{array}$ & 43 & 1510 & 106 & 5.71 & 62.8 & $\begin{array}{l}\text { University of } \\
\text { Fribourg/Universite } \\
\text { Paris-Saclay }\end{array}$ & Switzerland/France \\
\hline 2 & $\begin{array}{l}\text { Poirel, } \\
\text { Laurent }\end{array}$ & 43 & 1560 & 99 & 5.78 & 62.8 & $\begin{array}{l}\text { University of } \\
\text { Fribourg/Universite } \\
\text { Paris-Saclay }\end{array}$ & Switzerland/France \\
\hline 3 & $\begin{array}{l}\text { Rolain, } \\
\text { Jean Marc }\end{array}$ & 34 & 1346 & 54 & 5.05 & 47.1 & $\begin{array}{l}\text { Aix-Marseille } \\
\text { Université/AP-HM } \\
\text { Assistance } \\
\text { Publique - } \\
\text { Hôpitaux de } \\
\text { Marseille }\end{array}$ & France \\
\hline 4 & Li, Jian & 23 & 957 & 55 & 2.49 & 78.3 & $\begin{array}{l}\text { Monash } \\
\text { University/ } \\
\text { Monash Institute } \\
\text { of Pharmaceutical } \\
\text { Sciences }\end{array}$ & Australia \\
\hline 5 & $\begin{array}{l}\text { Ko, Kwan } \\
\text { Soo }\end{array}$ & 20 & 409 & 42 & 1.46 & 0 & $\begin{array}{l}\text { Sungkyunkwan } \\
\text { University/Asia } \\
\text { Pacific Foundation } \\
\text { for Infectious } \\
\text { Diseases APFID/ }\end{array}$ & Japan \\
\hline 6 & Doi, Yohei & 19 & 2753 & 57 & 15.71 & 63.2 & $\begin{array}{l}\text { University of } \\
\text { Pittsburgh/ Fujita } \\
\text { Health University } \\
\text { School of Medicine }\end{array}$ & $\begin{array}{l}\text { United } \\
\text { States/Japan }\end{array}$ \\
\hline 7 & $\begin{array}{l}\text { Feng, } \\
\text { Youjun }\end{array}$ & 19 & 544 & 32 & 3.98 & 42.1 & $\begin{array}{l}\text { Zhejiang } \\
\text { University/South } \\
\text { China Agricultural } \\
\text { University }\end{array}$ & China \\
\hline 8 & $\begin{array}{l}\text { Wang, } \\
\text { Yang }\end{array}$ & 18 & 2486 & 35 & 16.07 & 61.1 & $\begin{array}{l}\text { China Agricultural } \\
\text { University }\end{array}$ & China \\
\hline 9 & $\begin{array}{l}\text { Jayol, } \\
\text { Aurélie }\end{array}$ & 17 & 613 & 15 & 4.20 & 82.4 & $\begin{array}{l}\text { University of } \\
\text { Fribourg/ IAME } \\
\text { Infection } \\
\text { Antimicrobials } \\
\text { Modelling } \\
\text { Evolution }\end{array}$ & Switzerland/France \\
\hline 10 & $\begin{array}{l}\text { Rossolini, } \\
\text { Gian María }\end{array}$ & 17 & 972 & 73 & 5.88 & 29.4 & $\begin{array}{l}\text { University of } \\
\text { Florence }\end{array}$ & Italy \\
\hline
\end{tabular}

The 10 institutions with the largest number of documents are shown in Table 5. The University of Fribourg (Switzerland), Center National de la Recherche Scientifique (CNRS) (France) and Zhejiang University (China) occupy the top three places, respectively. However, the latter is the one with the highest number of citations $(2,956)$ and is the most productive with respect to polymyxin resistance ( $\mathrm{FWCI}=8.62)$. When a sub-analysis was carried out by continents, the University of Fribourg and CNRS predominate in Europe, and Zhejiang University in the Asian continent. University of Pittsburgh (USA) and Universidade de São Paulo (Brazil) do the same in North and South America, respectively. 
Table 5

Top ten productive institutions on polymyxin resistance (2009-2018)

\begin{tabular}{|c|c|c|c|c|c|c|c|c|}
\hline Rank & Institution & $\begin{array}{l}\text { Documents } \\
\mathrm{N}=833(\%)\end{array}$ & $\begin{array}{l}\text { Total } \\
\text { citation }\end{array}$ & Citations/document & $\begin{array}{l}\text { Number } \\
\text { of } \\
\text { authors }\end{array}$ & $\begin{array}{l}\text { International } \\
\text { collaboration; } \\
\text { national } \\
\text { collaboration } \\
(\%)\end{array}$ & FWCI & Country \\
\hline 1 & $\begin{array}{l}\text { University of } \\
\text { Fribourg }\end{array}$ & $44(5.3)$ & 1511 & 35.3 & 16 & $65.9 ; 31.8$ & 5.69 & Switzerland \\
\hline 2 & $\begin{array}{l}\text { Centre National } \\
\text { de la } \\
\text { Recherche } \\
\text { Scientifique }\end{array}$ & $41(4.9)$ & 1594 & 38.9 & 67 & $63.4 ; 36.6$ & 4.65 & France \\
\hline 3 & $\begin{array}{l}\text { Zhejiang } \\
\text { University }\end{array}$ & $40(4.8)$ & 2956 & 73.9 & 79 & $45.0 ; 45.0$ & 8.62 & China \\
\hline 4 & $\begin{array}{l}\text { Institut } \\
\text { National de la } \\
\text { santé et de la } \\
\text { recherche } \\
\text { médicale }\end{array}$ & $35(4.2)$ & 1389 & 39.7 & 51 & $57.1 ; 42.9$ & 4.95 & France \\
\hline 5 & $\begin{array}{l}\text { Aix-Marseille } \\
\text { Université }\end{array}$ & $34(4.1)$ & 1323 & 38.9 & 49 & $47.1 ; 50.0$ & 4.84 & France \\
\hline 6 & $\begin{array}{l}\text { Institut de } \\
\text { Recherche pour } \\
\text { le } \\
\text { Développement }\end{array}$ & $32(3.8)$ & 1301 & 40.7 & 43 & $50.0 ; 50.0$ & 5.04 & France \\
\hline 7 & $\begin{array}{l}\text { University of } \\
\text { Lausanne }\end{array}$ & $27(3.2)$ & 591 & 21.9 & 7 & $70.4 ; 29.6$ & 4.06 & Switzerland \\
\hline 8 & $\begin{array}{l}\text { Monash } \\
\text { University }\end{array}$ & $25(3.0)$ & 1080 & 43.2 & 54 & $80.0 ; 20.0$ & 2.64 & Australia \\
\hline 9 & $\begin{array}{l}\text { Universidade } \\
\text { de São Paulo }\end{array}$ & $22(2.6)$ & 554 & 25.2 & 77 & $0 ; 68.2$ & 2.91 & Brazil \\
\hline 10 & $\begin{array}{l}\text { Sungkyunkwan } \\
\text { University }\end{array}$ & $21(2.5)$ & 423 & 20.1 & 20 & $4.8 ; 42.9$ & 1.49 & Japan \\
\hline
\end{tabular}

The 10 journals with the highest number of publications on polymyxin resistance are shown in Table 6 . The first three places were for Antimicrobial Agents and Chemotherapy, International Journal of Antimicrobial Agents and Journal of Antimicrobial Chemotherapy with 140, 75 and 67 documents, respectively. However, only the first one maintains its place in terms of more citations and more authors. When the journal with the greatest impact was analyzed, the first place went to The Lancet Infectious Diseases with a FCWI of 17.91 and 137 citations/article. According to CS, 393 (47.4\%) of the documents on polymyxin resistance have been published in the top $10 \%$ of the best journals. 
Table 6

Top ten journals publishing on polymyxin resistance (2009-2018)

\begin{tabular}{|c|c|c|c|c|c|c|c|c|}
\hline Rank & Journal (country) & $\begin{array}{l}\text { Documents } \\
\mathrm{N}=833(\%)\end{array}$ & $\begin{array}{l}\text { Total } \\
\text { citation }\end{array}$ & Citations/document & $\begin{array}{l}\text { Number } \\
\text { of } \\
\text { authors }\end{array}$ & $\begin{array}{l}\text { CS } \\
2018\end{array}$ & $\begin{array}{l}\text { SJR } \\
2018\end{array}$ & $\mathrm{FWCl}$ \\
\hline 1 & $\begin{array}{l}\text { Antimicrobial Agents and } \\
\text { Chemotherapy (USA) }\end{array}$ & $140(16.8)$ & 5832 & 41.7 & 796 & 4.34 & 2.09 & 4.62 \\
\hline 2 & $\begin{array}{l}\text { International Journal of } \\
\text { Antimicrobial Agents } \\
\text { (Netherlands) }\end{array}$ & $75(9.0)$ & 1511 & 20.2 & 449 & 3.59 & 1.53 & 3.77 \\
\hline 3 & $\begin{array}{l}\text { Journal of Antimicrobial } \\
\text { Chemotherapy (UK) }\end{array}$ & $67(8.0)$ & 2609 & 38.9 & 443 & 4.24 & 2.14 & 5.68 \\
\hline 4 & $\begin{array}{l}\text { Frontiers in Microbiology } \\
\text { (Switzerland) }\end{array}$ & $28(3.4)$ & 871 & 31.1 & 211 & 4.30 & 1.63 & 2.29 \\
\hline 5 & $\begin{array}{l}\text { The Lancet Infectious } \\
\text { Diseases (UK) }\end{array}$ & $26(3.1)$ & 3584 & 137.9 & 137 & 6.53 & 9.46 & 17.91 \\
\hline 6 & $\begin{array}{l}\text { Diagnostic Microbiology and } \\
\text { Infectious Disease } \\
\text { (Netherlands) }\end{array}$ & $20(2.4)$ & 364 & 18.2 & 115 & 2.31 & 1.13 & 1.59 \\
\hline 7 & Eurosurveillance (France) & $19(2.3)$ & 1359 & 71.5 & 150 & 5.05 & 3.88 & 10.69 \\
\hline 8 & $\begin{array}{l}\text { Journal of Global } \\
\text { Antimicrobial Resistance (UK) }\end{array}$ & $19(2.3)$ & 136 & 7.2 & 106 & 1.94 & 0.83 & 1.54 \\
\hline 9 & $\begin{array}{l}\text { Journal of Clinical } \\
\text { Microbiology (USA) }\end{array}$ & $18(2.2)$ & 595 & 33.1 & 126 & 3.65 & 2.31 & 2.87 \\
\hline 10 & $\begin{array}{l}\text { Clinical Microbiology and } \\
\text { Infection (UK) }\end{array}$ & $15(1.8)$ & 675 & 45.0 & 118 & 4.51 & 2.65 & 4.05 \\
\hline
\end{tabular}

Furthermore, according to SJR and CS, Table 7 shows the number of documents sorted by the quartile of the journal in which they were published, showing that more documents are published in journals with better quartiles.

Table 7

Number of documents per journal quartile by Scimago Journal \& Country Rank and CiteScore

\begin{tabular}{|lll|}
\hline Bibliometric indicator & SJR & CS \\
\hline Quartiles & $\begin{array}{l}\text { Documents } \\
\text { N = 833 (\%) }\end{array}$ \\
\hline Q1 & $689(82.7)$ & $576(69.1)$ \\
\hline Q2 & $94(11.3)$ & $139(16.7)$ \\
\hline Q3 & $27(3.2)$ & $66(7.9)$ \\
\hline Q4 & $19(2.3)$ & $32(3.9)$ \\
\hline No Q & $4(0.5)$ & $20(2.4)$ \\
\hline SJR Scimago Journal \& Country Rank, CSCiteScore, Q quartile \\
\hline
\end{tabular}




\section{Discussion}

In other bibliometric studies $[19,22]$ in which the document type is reported, the reviews are in second place after the articles. In our study, although letters represent the second type of document with the highest percentage of publications, only articles and reviews are among the 10 most cited documents on polymyxin resistance. An underlying explanation is that The Lancet Infectious Diseases and to a lesser extent other journals (Antimicrobial Agents and Chemotherapy, International Journal of Antimicrobial Agents and Journal of Antimicrobial Chemotherapy) accept research for publication under the category of research letter as a form of rapid communication, especially on relevant topics. An example of this is the most cited letter (173 citations) in the period 2009-2018 that belongs to Falgenhauer L. et al. [28] published in 2016 in The Lancet Infectious Diseases and which deals with the mcr-1 gene that confers resistance to colistin in carbapenemase-producing gram-negative bacteria and betalactamases that spread in Germany.

In 2016 , there was a peak in the number of citations, exactly 8,033 citations, this is probably due to the great impact that the publication dealing with the paradigm shift had on the transfer mechanism of colistin resistance, which was considered only as a rare chromosomal mutation up to that time. Liu Y-Y et al. [29] demonstrated plasmid-mediated colistin resistance thanks to the mobilized colistin resistance ( $m c r-1)$ gene identified in pigs in China. Interestingly, in the same year another gene called $m c r-2$ was isolated in Eschericihia coli (E.coli) in Belgium [30]. In the following years other mcrgenes were identified: in 2017 the $m c r-3$ gene in E.coli in China [31], mcr-4 in E.coli and Salmonella enterica serovar Typhimurium in three countries (Italy, Spain and Belgium) [32], mcr-5 in E.coli and Salmonella Paratyphi B in Germany [33], and mcr-6 in Moraxella pluranimalium in the United Kingdom [34]; in 2018 the mcr-7.1 and mcr-8 gene, both in Klebsiella pneumoniae in China [35, 36]; in 2019 the mcr-9 gene in Salmonella enterica serovar Typhimurium in the USA [37]; and to date, the mcr-10 gene was isolated in Enterobacter roggenkampii in China [38]. This has contributed to the continuous growth of the scientific literature relevant to polymyxin resistance, although they did not cause the same impact after 2016, as citations decreased (Fig. 1).

As in our study, other bibliometric studies reported that the USA ranked first in the amount of scientific production in resistance to other antimicrobials $[19,20,22,23]$. Likewise, the USA also obtained the first place in those studies that analyzed the scientific production of a certain drug, such as tramadol [39], aspirin [40] or clavulanic acid [17]. Given the large number of documents from the USA $(n=146)$, it is logical to expect them to obtain the highest number of citations $(6,513)$. However, the UK achieved a significant number of citations $(3,587)$ with fewer documents $(n=44)$. This may be due to their great international collaboration (79.5\%), being 7.8 times more cited than the world average (Table 3). In addition, it has three publications within the 10 most cited documents on polymyxin resistance (Table 2: rank 1,7 , and 9).

Nordmann P. and Poirel L., who were the authors with the highest number of documents in polymyxin resistance, also have the highest number of documents in carbapenem resistance according to the bibliometric study carried out by Sweileh W. et al. [23]. Both authors (Nordmann P. and Poirel L.) have as affiliation the University of Fribourg and present multiple co-authorships in their researchs, of which the most cited (126 citations) deals with the role of the MgrB protein as a source of resistance to colistin in a series of Klebsiella pneumoniae [41]. Nonetheless, the most influential authors on polymyxin resistance were Doi Y. (USA) and Wang Y., (China) with a FWCl of 15.71 and 16.07, respectively. The fact that both authors are co-authors of the most cited article would explain their high FWCI (see Table 2). It is important to note that this is not their only publication in the top 10 (Table 2: rank 7).

As for the 10 institutions with the highest scientific production, none of them belongs to the USA. Univeristy of Zhejiang (China) was the institution whose publications caused the greatest impact with 2,956 citations and 79 authors, with Feng $Y$. being the most productive author with this affiliation (see Table 4). Despite this, the University of Fribourg (Switzerland) with only 16 authors obtained the highest number of documents $(n=44)$. It is also important to point out that, the University of São Paulo (Brazil), while not having international collaboration, ranked 9th among the most productive institutions (Table 5). Its important national collaboration (68.2\%) is noteworthy, being its greatest contribution on dissemination of the mcr-1 gene through samples collected in E. coli and other enterobacteria, evidencing an emerging resistance to colistin in the South American continent since 2012 [42].

Page $10 / 16$ 
Although Antimicrobial Agents and Chemotherapy, Journal of Antimicrobial Chemotherapy and Eurosurveillance were the journals in which the 10 most cited documents were published three times, twice and twice, respectively, The Lancet Infectious Diseases with only 26 documents was 16.91 times more cited than the world average, achieving 137.9 citations/article, which triples the number of citations/article obtained by the journal with the largest number of documents in our study (Antimicrobial Agents and Chemotherapy). However, Antimicrobial Agents and Chemotherapy is the only one that has remained among the 5 journals with the highest scientific production in other bibliometric studies, ranking first on carbapenem resistance [23] and antifungal triazole resistance [20], second in antimalarial drug resistance [19], and third in antimicrobial resistance among uropathogens [22].

Finally, there are some limitations and strengths in our research. First, like other bibliometric studies, some results may have been missing due to publication in non-indexed journals in Scopus. However, this is the first study on polymyxin resistance applying bibliometric indicators. Second, it was not possible to discern between articles related to humans and animals. Despite this, the relationship is closer than it seems because colistin is used as a growth promoter in the veterinary field [43]. Furthermore, horizontal transmission of $m c r$ genes occurs through multi-resistance plasmids from animals, humans, and retail meat $[43,44]$.

\section{Conclusion}

The number of documents on polymyxin resistance in Scopus has increased in the last decade. Most of the documents come from high-income countries, with the USA and China being the countries with the highest scientific activity in polymyxin resistance. This, together with the high-impact journals in which they were published, demonstrates the great importance of the subject and the rapid spread of AMR. Greater joint effort by clinicians, researchers and the pharmaceutical industries is still needed to confront this old enemy, which has become a global threat.

\section{Abbreviations}

AMR: Antimicrobial resistance; WHO: World Health Organization; GLASS: Global Antimicrobial Resistance Surveillance System; MeSH: Medical Subject Headings; MCR: Multivariate Curve Resolution; mcr: mobilized colistin resistance; FWCl: Field-Weighted Citation Impact; SJR: Scimago Journal \& Country Rank ;CS: CiteScore; h-index: The Hirsch Index; Q: quartile; USA: United States of America; UK: United Kingdom

\section{Declarations}

\section{Acknowledgements}

Not applicable.

\section{Authors' contributions}

Conceived the idea and designed the study: AQL and JPM. Analyzed the data: JPM. Drafting of the manuscript: AQL; Critical review of the manuscript's drafts: JPM. Both authors read and approved the final manuscript.

\section{Funding}

This study was self-funded.

\section{Availability of data and materials}

All data analyzed with SciVal in this study is included in Dataset 1: Data obtained from Scopus, a .CSV that contain list of studies analyzed.

\section{Ethics approval and consent to participate}

Not applicable. 


\section{Consent for publication}

Not applicable.

\section{Competing interests}

The authors declare that they have no competing interests.

\section{References}

1. World Health Organization. ANTIBACTERIAL AGENTS IN CLINICAL DEVELOPMENT. An analysis of the antibacterial clinical development pipeline, including tuberculosis [https://apps.who.int/iris/bitstream/handle/10665/258965/WHO-EMP-IAU2017.11-eng.pdf]. Accessed 7 June 2020.

2. Laxminarayan R, Duse A, Wattal C, Zaidi AKM, Wertheim HFL, Sumpradit N, et al. Antibiotic resistance-the need for global solutions. Lancet Infect Dis. 2013;13:1057-98.

3. Allcock S, Young EH, Holmes M, Gurdasani D, Dougan G, Sandhu MS, et al. Antimicrobial resistance in human populations: challenges and opportunities. Glob Heal Epidemiol Genomics. 2017;2:e16.

4. Luepke KH, Suda KJ, Boucher H, Russo RL, Bonney MW, Hunt TD, et al. Past, Present, and Future of Antibacterial Economics: Increasing Bacterial Resistance, Limited Antibiotic Pipeline, and Societal Implications. Pharmacotherapy. 2017;37:71-84.

5. Falagas, Matthew E; Kasiakou SK. Colistin: The Revival of Polymyxins for the Management of Multidrug-Resistant GramNegative Bacterial Infections. Clin Infect Dis. 2005;40:1333-41.

6. Azzopardi EA, Ferguson EL, Thomas DW. Colistin past and future: A bibliographic analysis. J Crit Care. 2013;28:219.e13-9.

7. Biswas S, Brunel JM, Dubus JC, Reynaud-Gaubert M, Rolain JM. Colistin: An update on the antibiotic of the 21st century. Expert Rev Anti Infect Ther. 2012;10:917-34.

8. World Health Organization. Global Antimicrobial Resistance Surveillance System (GLASS) Report. Early implementation [https://www.who.int/docs/default-source/searo/amr/global-antimicrobial-resistance-surveillance-system-(glass)-reportearly-implementation-2016-2017.pdf]. Accessed 7 June 2020.

9. Qureshi ZA, Hittle LE, O'Hara JA, Rivera JI, Syed A, Shields RK, et al. Colistin-resistant acinetobacter baumannii: Beyond carbapenem resistance. Clin Infect Dis. 2015;60:1295-303.

10. Cai Y, Chai D, Wang R, Liang B, Bai N. Colistin resistance of Acinetobacter baumannii: Clinical reports, mechanisms and antimicrobial strategies. J Antimicrob Chemother. 2012;67:1607-15.

11. Moffatt JH, Harper M, Harrison P, Hale JDF, Vinogradov E, Seemann T, et al. Colistin resistance in Acinetobacter baumannii is mediated by complete loss of lipopolysaccharide production. Antimicrob Agents Chemother. 2010;54:4971-7.

12. World Health Organization. Global Antimicrobial Resistance Surveillance System (GLASS). The detection and reporting of colistin resistance [https://apps.who.int/iris/bitstream/handle/10665/277175/WHO-WSI-AMR-2018.4-eng.pdf]. Accessed 7 June 2020.

13. Rebelo AR, Bortolaia V, Kjeldgaard JS, Pedersen SK, Leekitcharoenphon P, Hansen IM, et al. Multiplex PCR for detection of plasmid-mediated colistin resistance determinants, mcr-1, mcr-2, mcr-3, mcr-4 and mcr-5 for surveillance purposes. Eurosurveillance. 2018;23:1-11.

14. Borowiak M, Baumann B, Fischer J, Thomas K, Deneke C, Hammerl JA, et al. Development of a Novel mcr-6 to mcr-9 Multiplex PCR and Assessment of mcr-1 to mcr-9 Occurrence in Colistin-Resistant Salmonella enterica Isolates From Environment, Feed, Animals and Food (2011-2018) in Germany. Front Microbiol. 2020;11:1-8.

15. Nordmann P, Jayol A, Poirel L. Rapid detection of polymyxin resistance in Enterobacteriaceae. Emerg Infect Dis. 2016;22:1038-43.

16. Nordmann P, Jayol A, Poirel L. A universal culture medium for screening polymyxin-resistant gram-negative isolates. J Clin Microbiol. 2016;54:1395-9.

17. Ramirez-Malule H. Bibliometric analysis of global research on clavulanic acid. Antibiotics. 2018;7:102. 
18. Rodriguez-Morales AJ, Martinez-Pulgarin DF, Muñoz-Urbano M, Gómez-Suta D, Sánchez-Duque JA, Machado-Alba JE. Bibliometric Assessment of the Global Scientific Production of Nitazoxanide. Cureus. 2017;9:1-12.

19. Sweileh WM, Al-Jabi SW, Sawalha AF, AbuTaha AS, Zyoud SH. Bibliometric Analysis of Worldwide Publications on Antimalarial Drug Resistance (2006-2015). Malar Res Treat. 2017;2017:6429410.

20. Sweileh WM, Sawalha AF, Al-Jabi S, Zyoud SH. Bibliometric analysis of literature on antifungal triazole resistance: 1980 2015. Germs. 2017;7:19-27.

21. Gómez-Ríos D, Ramírez-Malule H. Bibliometric analysis of recent research on multidrug and antibiotics resistance (20172018). J Appl Pharm Sci. 2019;9:112-6.

22. Sweileh WM, Al-Jabi SW, Zyoud SH, Sawalha AF, Abu-Taha AS. Global research output in antimicrobial resistance among uropathogens: A bibliometric analysis (2002-2016). J Glob Antimicrob Resist. 2018;13:104-14.

23. Sweileh WM, Shraim NY, Al-Jabi SW, Sawalha AF, AbuTaha AS, Zyoud SH. Bibliometric analysis of global scientific research on carbapenem resistance (1986-2015). Ann Clin Microbiol Antimicrob. BioMed Central; 2016;15:1-11.

24. Baas J, Schotten M, Plume A, Côté G, Karimi R. Scopus as a curated, high-quality bibliometric data source for academic research in quantitative science studies. Quant Sci Stud. 2020;1:377-86.

25. Chang LLH, Phoa FKH, Nakano J. A New Metric for the Analysis of the Scientific Article Citation Network. IEEE Access. 2019;7:132027-32.

26. van Eck NJ, Waltman L. Software survey: VOSviewer, a computer program for bibliometric mapping. Scientometrics. 2010;84:523-38.

27. HIRSCH HA, McCARTHY CG FM. Polymyxin B and colistin: activity, resistance and crossresistance in vitro. Proc Soc Exp Biol Med. 1960;103:338-42.

28. Falgenhauer L, Waezsada SE, Yao Y, Imirzalioglu C, Käsbohrer A, Roesler U, et al. Colistin resistance gene mcr-1 in extendedspectrum $\beta$-lactamase-producing and carbapenemase-producing Gram-negative bacteria in Germany. Lancet Infect Dis. 2016;16:282-3.

29. Liu YY, Wang Y, Walsh TR, Yi LX, Zhang R, Spencer J, et al. Emergence of plasmid-mediated colistin resistance mechanism MCR-1 in animals and human beings in China: A microbiological and molecular biological study. Lancet Infect Dis. 2016;16:161-8.

30. Xavier BB, Lammens C, Ruhal R, Butaye P, Goossens H. Identification of a novel plasmid-mediated colistin- resistance gene, mcr-2 , in Escherichia coli , Belgium , June 2016. Eurosurveillance. 2016;21:6-11.

31. Yin W, Li H, Shen Y, Liu Z WS, Shen Z et al. Novel Plasmid-Mediated Colistin Resistance Gene mcr-3 in Escherichia coli. MBio. 2017;8:e00543-17.

32. Carattoli A, Villa L, Feudi C, Curcio L, Orsini S, Luppi A, et al. Novel plasmid-mediated colistin resistance mcr-4 gene in Salmonella and Escherichia coli, Italy 2013, Spain and Belgium, 2015 to 2016. Eurosurveillance. 2017;22:1-5.

33. Borowiak M, Fischer J, Hammerl JA, Hendriksen RS, Szabo I, Malorny B. Identification of a novel transposon-associated phosphoethanolamine transferase gene, mcr-5, conferring colistin resistance in d-tartrate fermenting Salmonella enterica subsp. enterica serovar Paratyphi B. J Antimicrob Chemother. 2017;72:3317-24.

34. AbuOun M, Stubberfield EJ, Duggett NA, Kirchner M, Dormer L, Nunez-Garcia J, et al. mcr-1 and mcr-2 (mcr-6.1) variant genes identified in Moraxella species isolated from pigs in Great Britain from 2014 to 2015. J Antimicrob Chemother. 2017;72:274549.

35. Yang YQ, Li YX, Lei CW, Zhang AY, Wang HN. Novel plasmid-mediated colistin resistance gene mcr-7.1 in Klebsiella pneumoniae. J Antimicrob Chemother. 2018;73:1791-5.

36. Wang X, Wang Y, Zhou Y, Li J, Yin W, Wang S, et al. Emergence of a novel mobile colistin resistance gene, mcr-8, in NDMproducing Klebsiella pneumoniae article. Emerg Microbes Infect. 2018;7:1-9.

37. Carroll LM, Gaballa A, Guldimann C, Sullivan G, Henderson LO, Wiedmanna M. Identification of Novel Mobilized Colistin Resistance Gene mcr- 9 in a Multidrug-Resistant, Colistin-Susceptible Salmonella enterica Serotype Typhimurium Isolate. MBio. 2019;10:1-6. 
38. Wang C, Feng Y, Liu L, Wei L, Kang M, Zong Z. Identification of novel mobile colistin resistance gene mcr-10. Emerg Microbes Infect. 2020;9:508-16.

39. Sweileh WM, Shraim NY, Zyoud SH, Al-Jabi SW. Worldwide research productivity on tramadol: a bibliometric analysis. Springerplus. 2016;5:1108.

40. Al-Jabi SW. Global Trends in Aspirin Resistance-Related Research from 1990 to 2015: A Bibliometric Analysis. Basic Clin Pharmacol Toxicol. 2017;121:512-9.

41. Poirel L, Jayol A, Bontron S, Villegas MV, Ozdamar M, Türkoglu S, et al. The mgrB gene as a key target for acquired resistance to colistin in Klebsiella pneumoniae. J Antimicrob Chemother. 2015;70:75-80.

42. Fernandes MR, Moura Q, Sartori L, Silva KC, Cunha MP, Esposito F, et al. Silent dissemination of colistin-resistant Escherichia coli in South America could contribute to the global spread of the mcr-1 gene. Eurosurveillance. 2016;21:1-6.

43. Gharaibeh MH, Shatnawi SQ. An overview of colistin resistance, mobilized colistin resistance genes dissemination, global responses, and the alternatives to colistin: A review. Vet World. 2019;12:1735-46.

44. Hasman H, Hammerum AM, Hansen F, Hendriksen RS, Olesen B, Agers $\varnothing$ Y, et al. Detection of mcr-1 encoding plasmidmediated colistin-resistant escherichia coli isolates from human bloodstream infection and imported chicken meat, denmark 2015. Eurosurveillance. 2015;20:1-5.

45. Olaitan AO, Morand S, Rolain JM. Mechanisms of polymyxin resistance: Acquired and intrinsic resistance in bacteria. Front Microbiol. 2014;5:1-18.

46. Tumbarello M, Trecarichi EM, De Rosa FG, Giannella M, Giacobbe DR, Bassetti M, et al. Infections caused by KPC-producing Klebsiella pneumoniae: Differences in therapy and mortality in a multicentre study. J Antimicrob Chemother. 2015;70:213343.

47. Adams MD, Nickel GC, Bajaksouzian S, Lavender H, Murthy AR, Jacobs MR, et al. Resistance to colistin in Acinetobacter baumannii associated with mutations in the PmrAB two-component system. Antimicrob Agents Chemother. 2009;53:362834.

48. Beceiro A, Llobet E, Aranda J, Bengoechea JA, Doumith M, Hornsey M, et al. Phosphoethanolamine modification of lipid A in colistin-resistant variants of Acinetobacter baumannii mediated by the pmrAB two-component regulatory system. Antimicrob Agents Chemother. 2011;55:3370-9.

\section{Figures}




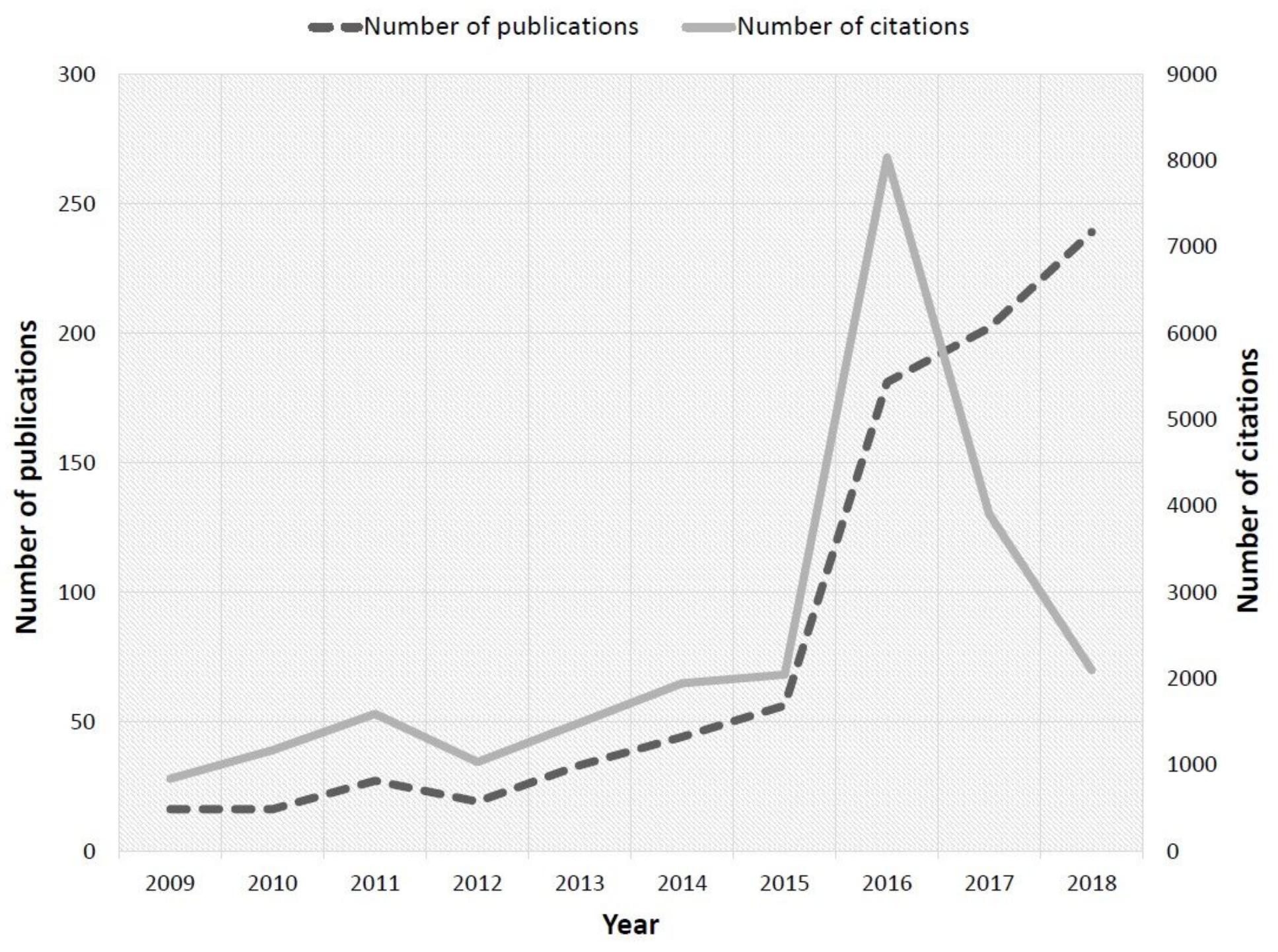

Figure 1

Growth of publications and citations for polymyxin resistance (2009-2018) 


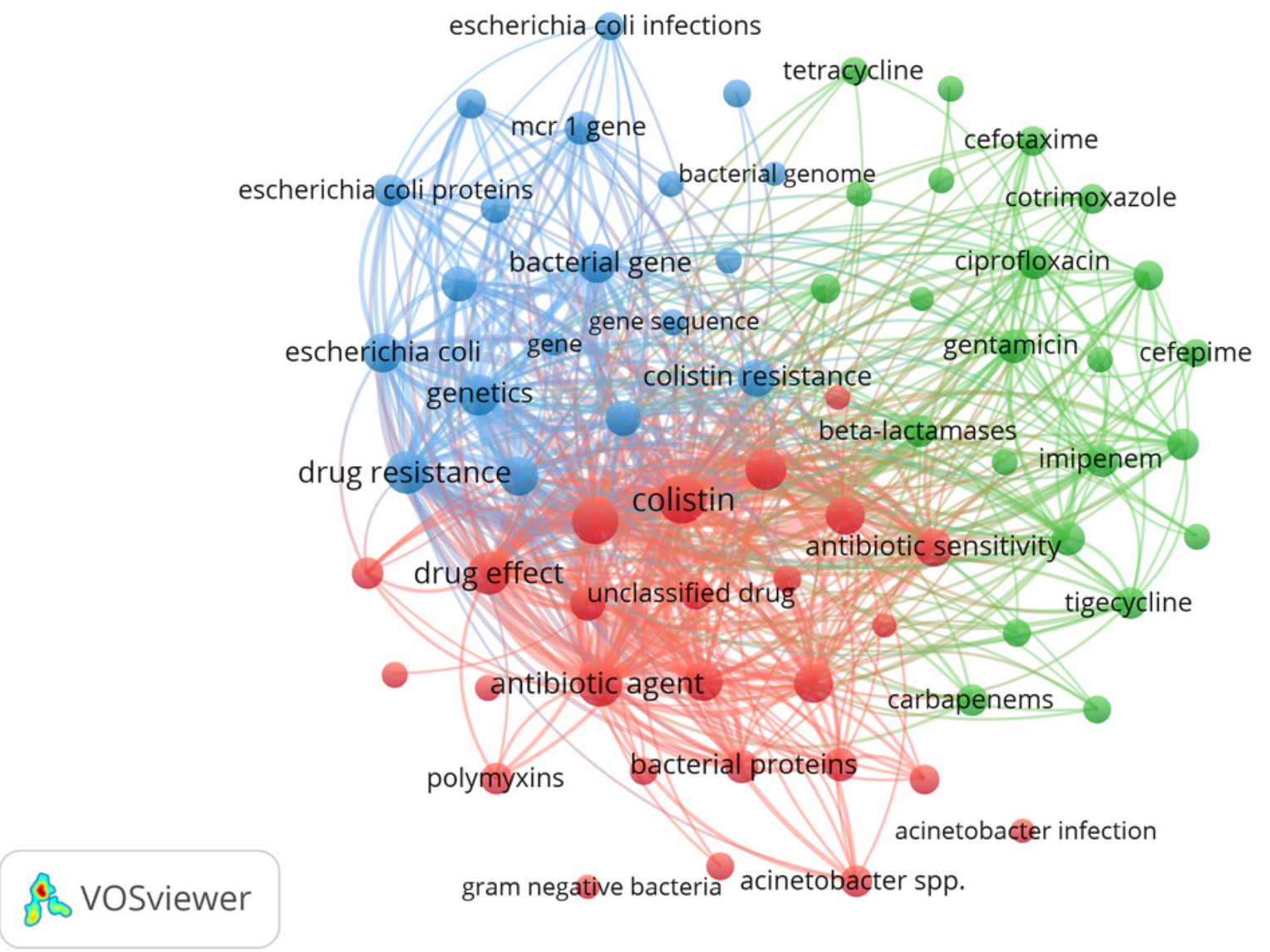

Figure 2

Research topics clustered by mapping of co-occurrences of terms for publications related to polymyxin resistance. Of the 5,731 terms, 69 terms occurred at least 100 times. The size of the circles represents the occurrences of terms in title/key. The largest set of connected terms consists of 68 terms in three clusters. The three clusters can be interpreted as: "bacteria commonly associated with an emerging polymyxin resistance (red cluster, 26 items)", "drugs used in combination for multidrug-resistant organisms (green cluster, 23 items)", and "genetics of polymyxin resistance (blue cluster, 19 items)"

\section{Supplementary Files}

This is a list of supplementary files associated with this preprint. Click to download.

- Additionalfile1.csv 